\title{
PENGEMBANGAN PERANGKAT PEMBELAJARAN IPA-BIOLOGI MENGGUNAKAN MODEL PEMBELAJARAN BERDASARKAN MASALAH DI MADRASAH TSANAWIYAH
}

\author{
Al Wardah \\ MTs Negeri Barabai \\ Email: al_wardah17@yahoo.com
}

\begin{abstract}
ABSTRAK
Hasil supervisi klinis terhadap perangkat RPP yang dibuat oleh guru-guru IPA dilingkungan MTsN Barabai hanya mengarah pada penguasaan konsep dan tidak mengarah pada penguasaan keterampilan berpikir. Memunculkan keterampilan berpikir kritis siswa perlu didukung oleh suatu model pembelajaran yang tepat, salah satu di antaranya adalah model pembelajaran berdasarkan masalah. Model pembelajaran ini memberikan kesempatan kepada guru untuk menggali keterampilan berpikir kritis dan berpikir kreatif. Penelitian pengembangan ini bertujuan menghasilkan perangkat pembelajaran yang layak, praktis dan efektif. Jenis penelitian pengembangan menggunakan model prosedural. Subjek uji coba lapangan adalah siswa kelas VII F dan VII G MTsN Barabai. Seluruh data diperoleh dari instrumen pengumpulan data dan dianalisis secara deskriptif. Hasil penelitian menunjukkan perangkat pembelajaran tergolong cukup layak berdasarkan 1) hasil uji kelayakan dari tim pakar dan 2) hasil uji keterbacaan siswa menunjukkan bahan ajar dan LKS layak digunakan setelah melalui revisi. Perangkat pembelajaran tergolong praktis, karena: 1) hasil keterlaksanaan perangkat RPP tergolong kategori sangat baik, 2) hasil respon siswa tergolong kategori sangat respon. Perangkat pembelajaran tergolong efektif karena: 1) hasil belajar kognitif tergolong tuntas sesuai dengan KKM, 2) keterampilan berpikir kritis siswa pada kegiatan membuat rumusan pertanyaan, menentukan prosedur penyelidikan, menganalisa data, dan membuat rumusan kesimpulan tergolong baik, 3) aktivitas guru dalam hal ini masih termasuk dominan,4) aktivita siswa menonjol pada 6 dari 9 parameter. 5) keterampilan psikomotor siswa tergolong baik, 6) perilaku berkarakter meliputi teliti dan bekerjasama tergolong baik, 7) keterampilan sosial siswa yaitu bertanya termasuk kategori baik,
\end{abstract}

Kata Kunci: perangkat pembelajaran, MPBM, layak, praktis, efektif.

\begin{abstract}
The result of clinical supervision on the lesson plan made by the natural sciences' teachers in MTsN Barabai that only covers the mastery of concept and not on the mastery of cognitive skill. To reveal the critical thinking ability of the students, an accurate learning model such as problem-based learning model is needed. This learning model is giving the teachers a chance to deepen the critical and creative thinking skills. The researchin developing the media is using procedural model. The subject of the reseach is the grade VII F and G of MTsN Barabai. The collected data from the instrument is analysed descriptively. The result of the research showed that the learning media is appopriate based on 1) Experts' validation ad 2) Readability test from the students that showed the media and workbook is appopriate to be used after passing the revision. The learning media is categorized as effective because: 1) the cognitive learning is complete based on the passing criteria, 2) critical thinking skills of the students on questioning, determining the procedure for investigating, analysing data, ad making conclusion are
\end{abstract}


categorized as good, 3) teachers' activity is still on dominant level, 4) students activity is showed on the 6 from 9 parameters, 5) students' psychomotor is categorized as good, 6) characters attitude is covering the dilligency and groupwork is categorized as good, 7) students' social skill such as questioning is categorized s good.

Keywords: Learning media, MPBM, appopriate, practical, effective.

\section{PENDAHULUAN}

Berdasarkan supervisi klinis terhadap perangkat RPP yang dibuat oleh guru-guru IPA di lingkungan MTsN Kabupaten Hulu Sungai Tengah, guru menggunakan RPP buatan bersama secara kolektif melalui kegiatan MGMP. Perangkat RPP yang dibuat adalah perangkat KTSP 2006, namun belum berbentuk buku. Perangkat RPP ini sudah memperlihatkan keterampilan berpikir akan tetapi tidak memperihatikan kemampuan berpikir. Guru belum berpikir untuk mengembangkan bahan ajar sesuai dengan kondisi lingkungan siswa berada. Pembelajaran hanya mengarah pada penguasaan konsep dan tidak mengarah pada penguasaan keterampilan berpikir.

Model Pembelajaran Berdasarkan Masalah (PBM) merupakan salah satu model yang memberikan kesempatan kepada guru untuk menggali keterampilan berpikir kritis dan berpikir kreatif. Kedua keterampilan berpikir ini merupakan keterampilan berpikir tingkat tinggi (high order thinking skill) yang selalu ditekankan dalam pembelajaran sains modern.

Penelitian pengembangan pembelajaran menggunakan model PBM sudah pernah dilaporkan. Herlina (2014) melaporkan 1) hasil belajar kognitif sudah mencapai ketuntasan klasikal (> 85\%), 2) keterampilan berpikir tingkat tinggi dicapai oleh sebagian besar, 3) guru mampu menggunakan perangkat pembelajaran tergolong baik, 4) pmbelajaran berpusat pada siswa, 5) perilaku berkarakter dan keterampilan sosial siswa mengalami peningkatan dari pertemuan 1 dan pertemuan 2 .
Menurut Nur (2011) di dalam pembelajaran guru dituntut untuk mengurangi kemampuan siswa di bidang kognitif rutin dan manual rutin. Akan tetapi ditingkatkan di bidang berpikir tingkat tinggi dan komunikasi kompleks. Salah satu cara yang mungkin dapat dilakukan adalah mengembangkan perangkat pembelajaran menggunakan model PBM. Salah satu topik yang dipelajari di SMP dan dapat menggali keterampilan berpikir kritis adalah topik interaksi makhluk hidup dengan lingkungannya. Topik ini mengajak siswa untuk berinteraksi langsung dengan lingkungan alami sehingga tercipta pembelajaran bermakna. Oleh karena itu perlu dikembangkan perangkat pembelajaran yang layak, praktis dan efektif.

Pembelajaran IPA topik interaksi makhluk hidup dengan lingkungannya masih menggunakan pembelajaran yang berpusat pada guru, padahal pembelajaran tidak bisa hanya dibayangkan, tetapi langsung melalui pengamatan pada saat proses pembelajaran. Permasalahan yang dihadapi selama ini adalah a) pembelajaran berpusat kepada guru, b) pembelajaran tidak sesuai dengan skenario yang ada di RPP, c) siswa pada dasarnya senang melakukan pengamatan tetapi guru belum memfasilitasi kemampuan berpikir siswa, d) belum ada model dan contoh perangkat yang dapat mengakomodir siswa untuk mengembangkan kemampuan berpikirnya. 


\section{METODE PENELITIAN}

Penelitian pengembangan ini menekankan pada langkah-langkah evaluasi formatif dari 6 langkah (Peffers, 2007), yaitu mengidentifikasi masalah, mendeskripsikan tujuan, merancang dan mengembangkan perangkat RPP, melaksanakan tes, melaksanakan evaluasi, dan mengkomunikasikan hasil dan kesimpulan. Tahap uji coba produk menggunakan model Tessmer (Tessmer, 1993).

Uji coba produk dimaksudkan untuk menetapkan kelayakan, kepraktisan dan keefektivan. Subyek coba uji perorangan dari tim dosen yakni 1) Dr. H. Muhammad Zaini, M. Pd, Dosen Pascasarjana Pendidikan Biologi Unlam Banjarmasin 2) Ita, M. Pd, Dosen IAIN Antasari Banjarmasin 3) Ayatus Sa'adah, Dosen UIN Palangkaraya. Teknik penetapan subyek coba tim pakar secara purposive, Subyek uji coba perorangan dari kalangan siswa, yakni 3 orang siswa kelas VII D MTsN Barabai.

Subyek uji coba kelompok kecil berasal dari siswa kelas VIIG MTsN Barabai sebanyak 20 orang. Subyek uji coba lapangan berasal dari siswa kelas VII F MTsN Barabai berjumlah 40 orang. Uji lapangan bertujuan untuk menetapkan keefektivan. Langkahlangkah pengembangan yang diakhiri dengan uji lapangan menghasilkan prototipe.

Penelitian dilaksanakan di Madrasah Tsanawiyah Negeri Barabai dengan alamat jalan Abdul Muis Redhani No. 80 Barabai. Uji coba kelompok kecil dilaksanakan minggu ke 3 bulan mei 2015 sebanyak 4 pertemuan. uji coba lapangan dilaksanakan minggu ke 4 bulan Mei 2015 juga sebanyak 4 pertemuan.

Data yang dikumpulkan meliputi 1) data kelayakan RPP, Bahan ajar, dan LKS yang dikembangkan diperoleh dari hasil uji pakar, dan uji perorangan, 2) data kepraktisan diperoleh dari penilaian keterlaksanaan RPP dari guru mitra selama proses pembelajaran dan data respon siswa, 3) data keefektivan perangkat pembelajaran meliputi: data hasil belajar, data aktivitas guru, data aktivitas siswa, data keterampilan psikomotor, data perilaku berkarakter dan data keterampilan sosial.

\section{HASIL DAN PEMBAHASAN}

Pendapat tim ahli tentang perangkat pembelajaran disajikan pada Tabel 1.

Tabel 1. Hasil Penilaian Tim Ahli terhadap Perangkat Pembelajaran

\begin{tabular}{|c|c|c|c|c|c|}
\hline \multirow[b]{2}{*}{ Komponen } & \multicolumn{3}{|c|}{ Nilai Validator (\%) } & \multirow{2}{*}{$\begin{array}{c}\text { Skor } \\
\text { Rata-rata } \\
(\%)\end{array}$} & \multirow[b]{2}{*}{ Kesimpulan } \\
\hline & V1 & $\mathrm{V} 2$ & V3 & & \\
\hline Silabus & 85 & 75 & 72 & 77,3 & Cukup layak \\
\hline $\begin{array}{l}\text { Rencana Pelaksanaan } \\
\text { Pembelajaran }\end{array}$ & 85,9 & 76 & 75 & 79,1 & Cukup layak \\
\hline Bahan Ajar & 82,8 & 78,1 & 76,5 & 79,1 & Cukup layak \\
\hline LKS & 87,5 & 80 & 80 & 82,5 & Cukup layak \\
\hline LP & 89,5 & 79,1 & 75 & 81,2 & Cukup layak \\
\hline Media Pembelajaran & 85 & 80 & 7,75 & 80,8 & Cukup layak \\
\hline
\end{tabular}

Sumber: Hasil Pengolahan data

Kategori: 85,01 - 100,00\% ( Sangat valid), 70,01 - 85,00\% (Cukup valid), 50,01 - 70,00\% (Kurang valid), 01,00 - 50,00\% (Tidak valid), 
Semua komponen perangkat pembelajaran pada Tabel 1 cukup layak digunakan dengan revisi kecil.
Ringkasan uji keterbacaan oleh siswa disajikan pada Tabel 2. Hasil penilaian siswa tentang bahan ajar dan LKS pada Tabel 2 tergolong baik.

Tabel 2. Uji Penilaian dan Pendapat Siswa Terhadap LKS dan Bahan Ajar

\begin{tabular}{cclcccc}
\hline \multirow{2}{*}{ No } & $\begin{array}{c}\text { Nama } \\
\text { siswa }\end{array}$ & Komponen & $\begin{array}{c}\text { Skor } \\
\text { LKS }\end{array}$ & Kategori & $\begin{array}{c}\text { Skor } \\
\text { bahan ajar }\end{array}$ & Kategori \\
\hline 1 & IP & Materi & 3,81 & Baik & 4,00 & Baik sekali \\
& & Kebahasaan & 3,92 & Baik & 3,33 & Baik \\
& & Penyajian & 3,67 & Baik & 4,00 & Baik sekali \\
& & & & & & \\
2 & SF & Materi & 3,75 & Baik & 3,75 & Baik \\
& & Kebahasaan & 3,92 & Baik & 4,00 & Baik \\
& & Penyajian & 3,42 & Baik & 3,00 & Baik \\
& & & & & & \\
3 & MZ & Materi & 3,81 & Baik & 3,75 & Baik \\
& & Kebahasaan & 3,58 & Baik & 3,67 & Baik \\
& & Penyajian & 3,58 & Baik & 3,67 & Baik \\
& \multirow{6}{*}{ Skor rata-rata } & 3,75 & Baik & 3,68 & baik \\
\hline
\end{tabular}

Keterangan : 1-1,9 : Kurang sekali, $\quad$ 2-2,9 : Kurang, $\quad 3-3,9$ : Baik, 4 : Baik sekali

Rata-rata penilaian terhadap LP dapat $\quad 3$. penilaian dan pendapat siswa terhadap dilihat pada Tabel 3. Berdasarkan Tabel lembar penilaian juga sudah baik.

Tabel 3. Rata-rata Penilaian Siswa Terhadap Lembar Penilaian

\begin{tabular}{|c|c|c|c|c|}
\hline No & $\begin{array}{l}\text { Nama } \\
\text { siswa }\end{array}$ & Komponen & Skor Penilaian & Kategori \\
\hline \multirow[t]{3}{*}{1} & $\mathrm{IP}$ & Kelengkapan & 3,00 & Baik \\
\hline & & Kebahasaan & 3,25 & Baik \\
\hline & & Penyajian & 3,83 & Baik \\
\hline \multirow[t]{3}{*}{2} & SF & Kelengkapan & 3,00 & Baik \\
\hline & & Kebahasaan & 3,38 & Baik \\
\hline & & Penyajian & 3,16 & Baik \\
\hline \multirow[t]{4}{*}{3} & $\mathrm{MZ}$ & Kelengkapan & 3,00 & Baik \\
\hline & & Kebahasaan & 3,29 & Baik \\
\hline & & Penyajian & 3,67 & Baik \\
\hline & & rata-rata & 3,32 & Baik \\
\hline
\end{tabular}

Keterangan : 1-1,9 : Kurang sekali, 2-2,9 : Kurang, 3-3,9 : Baik, 4 : Baik sekali 
Uji kelompok kecil meliputi kemampuan respon siswa. Ringkasan kemampuan guru guru dalam menggunakan perangkat dan mitra mengajar seperti Tabel 4.

Tabel 4. Rata-rata Keterlaksanaan Perangkat Pembelajaran

\begin{tabular}{lll}
\hline \multicolumn{1}{c}{ Aspek yang dinilai } & \multicolumn{2}{c}{ Rata-rata } \\
\cline { 2 - 3 } & Nilai & Kategori \\
\hline Mengorientasikan siswa kepada masalah & 4 & sangat baik \\
Mengorganisasikan siswa untuk belajar & 3,88 & sangat baik \\
Membantu penyelidikan mandiri atau kelompok & 3,72 & sangat baik \\
Mengembankan serta menyajikan hasil karya serta memamerkannya & 3,75 & sangat baik \\
Menganalisis dan mengevaluasi proses pemecahan masalah. & 3,53 & sangat baik \\
\hline
\end{tabular}

Keterangan : Kurang sekali $=0-1,5 \quad$ Kurang $=1,6-2,5 \quad$ Baik $=2,6-3,5 \quad$ Sangat baik $=3,6-$ 4,0

Tabel 4. menunjukkan RPP dapat digunakan untuk uji lapangan. Respon siswa terhadap kegiatan pembelajaran secara umum menunjukkan respon positif.

Data keefektivan diperoleh meliputi hasil belajar kognitif produk dan kognitif proses, keterampilan berpikir tingkat kritis, keterampilan guru dalam menggunakan

perangkat, aktivitas guru selama mengajar, aktivitas siswa dalam pembelajaran, respon siswa, perilaku berkarakter serta keterampilan sosial.

Rata-rata hasil belajar kognitif produk disajikan pada Tabel 5. Hasil belajar siswa telah mencapai ketutasan pada postes.

Tabel 5. Rata-rata Hasil Belajar Siswa

\begin{tabular}{llccc}
\hline \multirow{2}{*}{ No } & Jenis hasil belajar & Hasil belajar & \multirow{2}{*}{ \% tutas } \\
\cline { 3 - 5 } & & 38 & 2 & 95 \\
\hline 40 & kognitif produk & 40 & 0 & 100 \\
\hline 40 & kognitif proses & tidak tuntas & 2 \\
\hline
\end{tabular}

Keterangan $: \mathrm{TT}=$ Tidak Tuntas, $\mathrm{T}=$ Tuntas $\quad$ Kriteria Ketuntasan Minimum $(\mathrm{KKM})=70$

Rata-rata ringkasan keterampilan berpikir kritis siswa disajikan pada Tabel 6.

Tabel 6. Rata-rata Keterampilan Berpikir Kritis

\begin{tabular}{|c|c|c|c|c|c|c|c|c|}
\hline \multirow[t]{2}{*}{$\mathrm{N}$} & \multicolumn{2}{|c|}{ Merumuskan Pertanyaan } & \multicolumn{2}{|c|}{$\begin{array}{l}\text { Menentukan } \\
\text { Prosedur } \\
\text { Penyelidikan }\end{array}$} & \multicolumn{2}{|c|}{$\begin{array}{l}\text { Menganalisis } \\
\text { Data }\end{array}$} & \multicolumn{2}{|c|}{$\begin{array}{l}\text { Merumuskan } \\
\text { Kesimpulan }\end{array}$} \\
\hline & Skor & rata-ratai & Skor & rata-rata & Skor & rata-rata & Skor & rata-rata \\
\hline 40 & 105 & 2,62 & 104 & 2,6 & 98 & 2,45 & 101 & 2,52 \\
\hline \multicolumn{5}{|c|}{ Keterangan : 4 = Sangat baik , 3= baik, } & \multicolumn{2}{|c|}{ 2=Cukup baik , } & \multicolumn{2}{|c|}{$1=$ Kurang } \\
\hline \multicolumn{5}{|c|}{$\begin{array}{l}\text { Tabel 6. memperlihatkan hasil rata- } \\
\text { keterampilan berpikir kritis cukup baik. } \\
\text { Ringkasan aktivitas guru selama }\end{array}$} & $\begin{array}{l}\tan \mathrm{m} \\
\text { bel } 7 \\
\text { uasai l }\end{array}$ & $\begin{array}{l}\text { igajar d } \\
\text { menunj } \\
\text { giatan }\end{array}$ & $\begin{array}{l}\text { ajikan } \\
\text { kkan } \\
\text { mbela }\end{array}$ & $\begin{array}{l}\text { ada Tabel } \\
\text { ru masih } \\
\text { an. }\end{array}$ \\
\hline
\end{tabular}

Al Wardah, Pengembangan Perangkat Pembelajaran IPA-Biologi Menggunakan Model Pembelajaran Berdasarkan Masalah di Madrasah Tsanawiyah 
Tabel 7. Rata-rata Aktivitas Guru selama Mengajar

\begin{tabular}{|c|c|c|c|c|c|c|c|c|c|c|}
\hline \multirow[t]{2}{*}{ No } & \multirow[t]{2}{*}{ Nama Guru } & & \multicolumn{7}{|c|}{$\begin{array}{c}\text { Skor Aktivitas Guru Setiap } 5 \text { menit pada } \\
\text { Parameter Aktivitas }\end{array}$} & \multirow[t]{2}{*}{$\Sigma$} \\
\hline & & & 1 & 2 & 3 & 4 & 5 & 6 & 7 & \\
\hline \multirow{3}{*}{1.} & NDAH & $F$ & 7 & 10 & 16 & 17 & 13 & 11 & 6 & 80 \\
\hline & RUSMALINA, MPd & $\%$ & 8.75 & 12.50 & 20.00 & 21.25 & 16.25 & 13.75 & 7.50 & 100 \\
\hline & Kategori & & $\mathrm{R}$ & $\mathrm{T}$ & $\mathrm{T}$ & $\mathrm{T}$ & $\mathrm{T}$ & $\mathrm{T}$ & $\mathrm{R}$ & \\
\hline
\end{tabular}

Sumber : hasil olah data

Kategori: < 10\% rendah (baik), > 10\% tinggi (buruk); $(\mathrm{T}=$ Buruk dan $\mathrm{R}=$ Baik).

1. Guru menginformasikan tujuan pembelajaran, memotivasi siswa agar terlibat dalam orientasi masalah yang dipilih.

2. Guru mengarahkan siswa untuk mendefenisikan dan mengorgani-sasikan tugas belajar yang berhubungan dengan masalah yang akan dibahas.

3. Guru membimbing siswa untuk mengumpulkan informasi yang sesuai.

4. Guru membimbing siswsa melakukan

Rata-rata aktivitas siswa selama belajar dari 4 kali pertemuan dengan 9 pengamatan/ eksperimen untuk mendapatkan jawaban pemecahan masalah

5. Guru membantu siswa merancang dan menyajikan hasil karya.

6. Guru membantu siswa untuk melakukan analisa atau evaluasi terhadap penyelidikan mereka dan proses-proses yang telah digunakan.

7. Guru mengarahkan siswa untuk dapat membuat kesimpulan.

parameter disajikan pada Tabel 7.

Tabel 8. Rata-rata Aktivitas Siswa $(\mathbf{N}=5)$

\begin{tabular}{|l|c|cc|cc|c|cc|c|}
\hline pertemuan & \multicolumn{10}{|c|}{ Parameter } \\
\cline { 2 - 10 } & 1 & 2 & 3 & 4 & 5 & 6 & 7 & 8 & 9 \\
1 & 6,3 & 10,0 & 11,3 & 7,5 & 15,0 & 18,8 & 12,5 & 12,5 & 6,3 \\
\hline 2 & 9,2 & 9,2 & 10,0 & 7,5 & 17,5 & 10,8 & 14,2 & 15,0 & 6,7 \\
3 & 6,3 & 12,5 & 12,5 & 8,8 & 13,8 & 18,8 & 11,3 & 10,0 & 6,3 \\
4 & 8,3 & 9,2 & 14,2 & 5,8 & 15,8 & 21,7 & 8,3 & 8,3 & 8,3 \\
\hline rata-rata & 7,6 & 10,3 & 11,3 & 7,4 & 15,5 & 17,9 & 11,5 & 11 & 6,8 \\
$(\%)$ & & & & & & & & & \\
\hline kategori & $\mathrm{R}$ & $\mathrm{T}$ & $\mathrm{T}$ & $\mathrm{R}$ & $\mathrm{T}$ & $\mathrm{T}$ & $\mathrm{T}$ & $\mathrm{T}$ & $\mathrm{R}$ \\
\hline
\end{tabular}

Keterangan: $<10 \%$ : rendah $=\mathrm{R}$ (buruk) $>10 \%$ : tinggi $=\mathrm{T}($ baik)

1. Mendengarkan penjelasan guru/siswa lain

2. Mengamati orientasi masalah (kasus) yang disasjikan

3. Mengajukan pertanyaan kepda guru/siswa lain

4. Menulis hal-hal yang relevan dengan KBM

5. Mengerjakan LKS
6. Mengumpulkan data/informasi

7. Membuat hasil karya/kelompok

8. Mempresentasikan hasil kerja kelompok

9. Merumuskan kesimpulan 
Tabel 8. memperlihatkan aktivitas siswa relevan, dan merumuskan kesimpulan.

Data tentang keterampilan masih perlu perbaikan yakni mendengarkan penjelasan guru, menulis hal-hal yang psikomotorik disajikan pada Tabel 9.

Tabel 9. Rata-rata Psikomotor Siswa Selama Pembelajaran $(\mathbf{N}=5)$

\begin{tabular}{|c|c|c|c|c|c|}
\hline \multirow{2}{*}{ pertemuan } & \multicolumn{5}{|c|}{ Parameter } \\
\cline { 2 - 6 } & 1 & 2 & 3 & 4 & 5 \\
\hline 1 & 7,5 & 22,4 & 15,8 & 19 & 11,5 \\
\hline 2 & 15,3 & 24,4 & 14.9 & 11,4 & 18,8 \\
\hline 3 & 8 & 23,5 & 15,3 & 15,3 & 14,8 \\
\hline 4 & 8 & 23,5 & 13,8 & 19,1 & 11.5 \\
\hline $\begin{array}{l}\text { rata-rata } \\
(\%)\end{array}$ & 8,17 & 23,45 & 14,1 & 12,52 & 13,56 \\
\hline kategori & $\mathrm{R}$ & $\mathrm{T}$ & $\mathrm{T}$ & $\mathrm{T}$ & $\mathrm{T}$ \\
\hline
\end{tabular}

Keterangan: $<10 \%$ : rendah $=\mathrm{R}$ (buruk) $>10 \%$ : tinggi $=\mathrm{T}$ (baik)

Keterangan:

1. Menentukan alat dan bahan

2. Menentukan langkah kerja

3. Membuat data hasil pengamatan

Berdasarkan Tabel 9. siswa masih kesulitan dalam menentukan alat dan bahan, oleh karena itu parameter ini perlu mendapat perhatian khusus.

Perilaku berkarakter siswa kelas $7 \mathrm{~F}$
4. Menganalisa data hasil pengamatan

5. Menyusun kesimpulan

Tabel 10. Perilaku Berkarakter Siswa (dipilih Kelas 7 F)

\begin{tabular}{|c|c|c|c|c|c|c|c|c|c|c|c|c|c|}
\hline \multirow{3}{*}{ NO } & \multirow{3}{*}{ Nama Siswa } & \multirow{2}{*}{\multicolumn{5}{|c|}{$\begin{array}{c}\text { Perilaku karakter } \\
\text { Teliti }\end{array}$}} & \multirow{3}{*}{ Hasil } & \multirow{2}{*}{\multicolumn{5}{|c|}{$\begin{array}{c}\text { Perilaku karakter } \\
\text { Bekerjasama }\end{array}$}} & \multirow{3}{*}{ Hasil } \\
\hline & & & & & & & & & & & & & \\
\hline & & 1 & 2 & 3 & 4 & 5 & & 1 & 2 & 3 & 4 & 5 & \\
\hline 1 & M. Nabiel F & - & $\sqrt{ }$ & $\sqrt{ }$ & - & $\sqrt{ }$ & B & $\sqrt{ }$ & - & $\sqrt{ }$ & $\sqrt{ }$ & - & B \\
\hline 2 & M. Rifqi R & $\sqrt{ }$ & - & - & $\sqrt{ }$ & $\sqrt{ }$ & B & $\sqrt{ }$ & $\sqrt{ }$ & - & - & $\sqrt{ }$ & B \\
\hline 3 & M. Lutfi R & - & $\sqrt{ }$ & $\sqrt{ }$ & - & - & $\mathrm{C}$ & - & - & $\sqrt{ }$ & $\sqrt{ }$ & - & $\mathrm{C}$ \\
\hline 4 & M. Rifaldi R & $\sqrt{ }$ & $\sqrt{ }$ & - & $\sqrt{ }$ & $\sqrt{ }$ & A & - & $\sqrt{ }$ & - & $\sqrt{ }$ & $\sqrt{ }$ & B \\
\hline 5 & Riyadh rezky & $\sqrt{ }$ & - & $\sqrt{ }$ & $\sqrt{ }$ & - & B & $\sqrt{ }$ & - & $\sqrt{ }$ & - & - & $\mathrm{C}$ \\
\hline
\end{tabular}

Keterangan:

\section{Teliti}

1. Memastikan setiap langkah untuk memastikan kebenaran.

2. Berhati-hati dalam setiap langkah kegiatan yang dilakukan.

dapat dilihat pada Tabel 9. Berdasarkan Tabel 10. keterampilan berkarakter selama proses pembelajaran melalui 2 perilaku karakter yang diamati rata-rata memuaskan. 
2. Jangan fokus pada kebutuhan sendiri. Sebaliknya fokus pada kebutuhan kelompok.

4. Tidak mengganggu orang lain, menemukan hal yang memiliki kesamaan

5. Mendorong orang untuk bekerja sama untuk mencapai hal-hal yang besar

3. Mencari cara untuk menyelesaikan perbedaan antara anda dan orang lain

Kategori:

A : Sangat baik menunjukkan (4-5 parameter), B : Memuaskan (3 parameter)

C : Menunjukkan kemajuan (2 parameter), D : Memerlukan perbaikan (1 parameter)

Keterampilan sosial (bertanya) disajikan pada Tabel 10. Berdasarkan Tabel 11.

keterampilan sosial bertanya rata-rata memuaskan.

Tabel 11. Keterampilan Sosial (diamati pada pertemuan 1)

\begin{tabular}{|c|c|c|c|c|c|c|}
\hline \multirow{2}{*}{ No. } & \multirow{2}{*}{ Nama Siswa } & \multicolumn{4}{|c|}{ Keterampilan bertanya } & \multirow[t]{2}{*}{ Hasil } \\
\hline & & 1 & 2 & 3 & 4 & \\
\hline 1. & M. Nabiel F & - & $\sqrt{ }$ & - & $\sqrt{ }$ & $\mathrm{C}$ \\
\hline 2. & M. Rifqi R & $\sqrt{ }$ & $\sqrt{ }$ & - & $\sqrt{ }$ & B \\
\hline 3. & M. Lutfi R & $\sqrt{ }$ & - & $\sqrt{ }$ & $\sqrt{ }$ & B \\
\hline 4. & M. Rifaldi R & $\sqrt{ }$ & $\sqrt{ }$ & $\sqrt{ }$ & $\sqrt{ }$ & A \\
\hline 5 & Riyadh Rezky & $\sqrt{ }$ & $\sqrt{ }$ & $\sqrt{ }$ & $\sqrt{ }$ & A \\
\hline
\end{tabular}

Keterangan:

1. Mengajukan pertanyaan jika tidak memahami Sesuatu, bukan berpura-pura tahu.

2. Menggunakan berbagai sumber daya untuk belajar seperti buku.

3. Melihat ke dalam latar belakang hal, orang, peristiwa.

4. Menggunakan kesempatan untuk berbicara dengan banyak orang untuk belajar apa yang mereka ketahui

Kategori:

A : Sangat baik menunjukkan (4-5 parameter), B : Memuaskan (3 parameter)

C : Menunjukkan kemajuan (2 parameter), D : Memerlukan perbaikan (1 parameter)

Berdasarkan uraian di atas perangkat pembelajaran yang dikembangkan layak, praktis, dan efektif. Sekalipun demikian masih diperlukan revisi, khususnya pada uji lapangan. Alifa (2012) menyatakan perangkat pembelajaran pada penelitian dianggap layak jika skor dari tim ahli berada pada kategori cukup layak atau sangat layak serta mendapat respon yang tinggi dari siswa. Ellis \& Levy (2010) menambahkan bahwa perangkat yang valid dapat memberikan perbedaan yang signifikan dengan pembelajaran menggunakan perangkat konvensional.
Hasil uji keterbacaan siswa untuk bahan ajar, LKS, dan lembar penilaian termasuk kategori baik. Menurut Sinambela (2005) melalui uji keterbacaan akan diketahui pemahaman siswa terhadap bahan yang digunakan dalam perangkat pembelajaran. Nur (2013) menjelaskan tujuan uji keterbacaan membetulkan kesalahan ketik, kalimat tidak jelas, petunjuk yang hilang, atau tidak jelas, contoh yang tidak sesuai, kosakata yang tidak dikenal, salah gambar atau halaman, dan gambar yang tidak komunikatif. 
Kepraktisan perangkat pembelajaran meliputi data kemampuan guru melaksanakan perangkat RPP dan data respon siswa. Guru mitra dapat mengajarkan perangkat pembelajaran. Hasil ini didukung penelitian sebelumnya (Fatnawati, 2014). Rumapea (2013) menjelaskan guru sebagai ujung tombak dalam implementasi kurikulum dituntut menjadi guru yang mampu meramu kurikulum 2013 secara tepat yaitu proses penilaian dan kompetensi mampu meningkatkan kompetensi siswa untuk menghasilkan lulusan yang mampu menghadapi tantangan global.

Respon siswa secara keseluruhan sangat positif, hal ini sejalan dengan temuan penelitian sebelumnya (Fatmawati, 2014; Klegeris \& Hurrens, 2011). Herlina (2014) juga melaporkan bahwa penggunaan PBM menghasilkan respon positif.

Keefektivan perangkat pembelajaran diketahui melalui uji lapangan. Hasil belajar kognitif produk sudah tuntas, begitu juga dengan hasil belajar kognitif proses. Rohliansyah \& Zaini (2013) pembelajaran yang memberikan kesempatan kepada siswa untuk melakukan aktivitas siswa tergolong pembelajaran efektif. Hasil belajar merupakan berakhirnya bagian dan puncak proses belajar (Dimyati \& Mudjiono, 2009). Rusman (2012) penguasaan pengetahuan dan keterampilan lebih efektif apabila individu, khususnya siswa dapat mengalaminya sendiri, bukan hanya menunggu informasi dan materi dari guru, tetapi berdasarkan pada usaha sendiri untuk menemukan pengetahuan dan keterampilan yang baru dan kemudian mengintegrasikannya dengan pengetahuan dan keterampilan yang sudah dimiliki sebelumnya. Proses belajar pada prinsipnya bertumpu pada struktur kognitif, yakni penataan fakta, konsep serta prinsip- prinsip, sehingga membentuk satu kesatuan yang memiliki makna bagi subjek didik.

Keterampilan berpikir kritis siswa rata-rata cukup baik. Akcay (2009) menyatakan bahwa penerapan pembelajaran kooperatif menggunakan model PBM dapat mengasah keterampilan berpikir kritis, analisis dan keterampilan memecahkan masalah yang komplek serta berkomunikasi. Yasir (2013) mengemukakan ciri berpikir kritis salah satunya siswa mampu mengotrol aktif proses berpikir untuk menemukan jawaban yang timbul dari pemikiran siswa sendiri.

Aktivitas guru masih dominan, Menurut Slameto (2003) dalam proses belajar mengajar guru mempunyai tugas untuk membimbing dan memberi fasilitas belajar bagi siswa untuk mencapai tujuan. Guru mempunyai tugas untuk membimbing dan membantu siswa yang mengalami kesulitan sehingga mampu mengarahkan siswa menuju sasaran proses pembelajaran yang hendak dicapai. Guru juga berupaya menciptkan kondisi belajar yang efektif, namun belum sepenuhnya tercapai.

Aktivitas siswa selama belajar ratarata cukup aktif, Menurut Knight (2007) siswa bukan makhluk pasif yang sekedar menanti guru mengisi akal pikirannya dengan banyak informasi. Herlina (2014) menjelaskan bahwa pembelajaran PBM dapat mendorong siswa untuk lebih aktif. Data aktivitas siswa yang dominan menunjukkan bahwa pembelajaran dengan menggunakan model pembelajaran berbasis masalah dapat meningkatkan aktivitas siswa.

Keterampilan psikomotorik termasuk kategori baik karena LKS berorientasi pada lingkungan sekolah, sehingga siswa dapat memahami dan melakukan keterampilan psikomotor sesuai dengan yang diharapkan. Arends (2001), 
mengemukakan model PBM terdiri atas lima langkah utama yang dimulai dengan guru memperkenalkan siswa dengan suatu situasi masalah dan diakhiri dengan penyajian dan analisis hasil kerja siswa. Amir (2010) menjelaskan angka penilaian yang diberikan kepada siswa dapat menggambarkan kinerja siswa secara utuh. Siswa dilatih untuk terampil dalam membuat hasil karya.

Keterampilan berkarakter siswa (teliti) sudah baik, demikian juga untuk kemampuan bekerja sama. Menurut Nur (2011) model PBM mengarahkan kelompok-kelompok kecil siswa bekerjasama memecahkan suatu masalah yang telah disepakati oleh guru dan siswa. Ketika guru sedang menerapkan pembelajaran tersebut, siswa menggunakan bermacam-macam keterampilan, prosedur pemecahan masalah dan berpikir tingkat tinggi. Sehingga pembelajaran berbasis masalah menuntut siswa aktif memecahkan masalah yang ada.

Keterampilan sosial siswa (keterampilan bertanya) menunjukkan kategori baik, hal ini sejalan dengan penelitian sebelumnya (Amir,2010). Pembelajaran berdasarkan masalah dapat mendorong terjadinya pengembangan kecakapan kerja tim dan dan kecakapan sosial. Kemampuan sosial bertanya siswa masih perlu digali dan dikembangkan lagi. Akinoglu \& Tandongan (2007) menyatakan bahwa keterampilan sosial , penyebaran informasi dan aktivitas siswa dapat dikembangkan pada pembelajaran kooperatif seperti PBM.

\section{SIMPULAN}

Penggunaan perangkat pembelajaran yang dikembangkan setelah diujicobakan terhadap siswa kelas VII F dan VIIG MTsN barabai dikatakan cukup layak berdasarkan pendapat tim pakar, dan uji keterbacaan menurut pendapat siswa.
Perangkat pembelajaran dinyatakan praktis berdasarkan 1) keterlaksanaan guru mitra tarhadap RPP sangat baik, 2) sebagian besar siswa sangat respons terhadap pelaksanaan pembelajaran berdasarkan masalah. Perangkat pembelajaran dikatakan efektif berdasarkan 1) hasil belajar kognitif produk dan proses tergolong tuntas, 2) keterampilan berpikir kritis tergolong baik, 3) aktivitas guru masih dominan, namun ada tanda-tanda menurun, 4) aktivita siswa tergolong aktif, 5) keterampilan psikomotor siswa tergolong baik, 6) perilaku berkarakter meliputi teliti dan bekerjasama tergolong baik, 7) keterampilan sosial siswa yaitu bertanya termasuk kategori baik.

\section{DAFTAR PUSTAKA}

Agustina Fatmawati. 2014. Pengembangan Perangkat Pembelajaran Konsep Pencemaran Lingkungan Menggunakan Model Pembelajaran Berdasarkan Masalah Terhadap Hasil Belajar dan Keterampilan Berpikir Kreatif Siswa SMA. Tesis tidak diterbitkan. Banjarmasin: Program Studi Magister pendidikan Biologi UNLAM.

Akcay, B. 2009. Problem-Based Learning in Science Education. Turkish Journal of Science Education. 6 (1). 26

Akinoglu, O \& Tandogan, O. 2007. The effects of Problem-Based Active Learning in Sciences Education on Students' Academic Achievement, Attitudeand Concept Leaning, Eurasia Journal of Matematics, Science \& Teknology Education, (Online), 3(1), 71-81

Alifia Nora Rahma, 2012. Pengembangan Perangkat Pembelajaran Model Inquiri Berpendekatan Sets Materi Kelarutan dan Hasil Kali Kelarutan 
untuk Menumbuhkan Keterampilan berpikir Kritis Matematis siswa SMP. Universitas Muhammadiyah Bengkulu

Arends, R 2001. Learning to teach. New York: McGrawHill

Amir, M. T. 2010. Inovasi Pendidikan Melalui Problem Based Learning: Bagaimana Pendidik Memberdayakan Pemelajar di Era Pengetahuan. Jakarta: Kencana

Dimyati \& Mudjiono. 2006. Belajar dan Pembelajaran. Jakarta: Rineka Cipta

Ellis, J Timothy . dan Y Levy. 2010. A Guide for Novice Researchers: Design and Development Research Methods. Proceedings of Informing Science \& IT Education Conference (InSITE) 2010. Nova Southeastern University, Graduate School of Computer and Information Sciences, Fort Lauderdale, Florida, USA

Herlina, L. 2014. Pengembangan Perangkat Pembelajaran Konsep Virus dengan Menggunakan Model Pembelajaran Berdasarkan Masalah Terhadap HasilBe lajar dan Keterampilan Berpikir Tingkat Tinggi Siswa di SMA. Tesis, Program Studi Magister Pendidikan Biologi, Universitas Lambung Mangkurat Banjarmasin (Tidak dipublikasikan).

Klegeris, A. \& Hurren, H. 2011. Problem-Based Learning in A Large Classroom setting: Methodology, Student Perception and Problem Solving Skills. Prosiding of EDULEARN11 Conference. 4-6 July 2011. Barcelona, Spain.

Knight, G. R. 2007. Filsafat Pendidikan. Yogyakarta: Gama Media.

Nur, M. 2011. Model Pembelajaran Berdasarkan Masalah. Surabaya: Universitas Negeri Surabaya.
Nur, M. 2013. Pendidikan dan Latihan Pembelajaran Inovatif dan Pengembangan Perangkat pembelajaran Bermuatan Keterampilan Berpikir dan Perilaku Berkarakter. Kerjasama Program Studi Magister Pendidikan Biologi PPs Unlam dengan Pusat Sains dan Matematika Sekolah (PSMS) UNESA

Peffers, K., T Tuunanen, M.A Rothenberger, \& S Chatterjee. (2007). A design science research methodology for information systems research. Journal of Management Information Systems.

Rohliansyah, P. \& Zaini, M. 2013. Pengembangan Perangkat Pembelajaran Model ASSURE pada Konsep Keanekaragaman Hayati dengan Model Advance Organizer melalui Pendekatan Lingkungan terhadap Aktivitas dan Hasil Belajar Siswa Kelas X. Jurnal Pendidikan Lingkungan. 1(1) Tahun 2013.

Rumapea, M,E. 2013. Kurikulum 2013 Yang Berkarakter. Jupiis.vol 5. No 2

Rusman, 2012. Model-Model Pembelajaran. Jakarta. Raja Grafindo Persada.

Sinambela, P. 2005. Keefektifan Model Pembelajaran Bedasarkan Masalah (Problem-Based Intruction) dalam Pembelajaran Matematika. Dari NetLibrary, (Online), (http:// netlibrary.com), diakses 17 Mei 2015.

Slameto, 2003. Belajar dan Faktor-faktor yang Mempengaruhinya. Jakarta. Rineka Cipta.

Yasir, Muhammad; dkk, 2013. Pengembangan Lembar Kerja(LKS) Berbasis Strategi Belajar Meta kognitif untuk meningkatkan Hasil Belajar pada Materi pewarisan Sifat manusia. http:/ejournal. Unesa.ac.id/ index.php/bioedu. Di akses 2 September 2013 